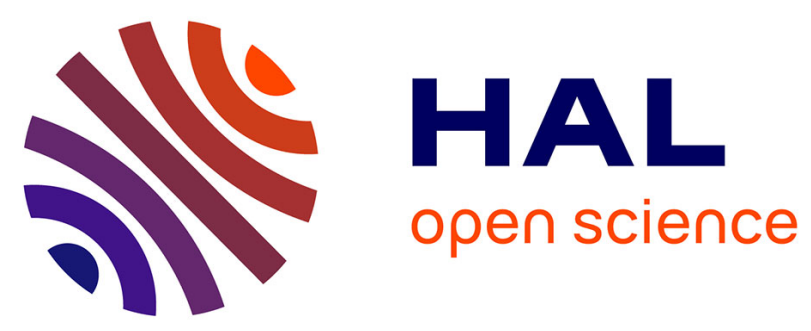

\title{
Design Defines the Effects of Nanoceria at a Low Dose on Soil Microbiota and the Potentiation of Impacts by the Canola Plant
}

Mohamed Hamidat, mohamed Barakat, Philippe Ortet, Corinne Chanéac, Jérôme Rose, Jean-Yves Bottero, Thierry Heulin, Wafa Achouak, Catherine Santaella

\section{To cite this version:}

Mohamed Hamidat, mohamed Barakat, Philippe Ortet, Corinne Chanéac, Jérôme Rose, et al.. Design Defines the Effects of Nanoceria at a Low Dose on Soil Microbiota and the Potentiation of Impacts by the Canola Plant. Environmental Science and Technology, 2016, 50 (13), pp.6892-6901. 10.1021/acs.est.6b01056 . hal-01427499

\author{
HAL Id: hal-01427499 \\ https://hal.science/hal-01427499
}

Submitted on 10 Feb 2022

HAL is a multi-disciplinary open access archive for the deposit and dissemination of scientific research documents, whether they are published or not. The documents may come from teaching and research institutions in France or abroad, or from public or private research centers.
L'archive ouverte pluridisciplinaire HAL, est destinée au dépôt et à la diffusion de documents scientifiques de niveau recherche, publiés ou non, émanant des établissements d'enseignement et de recherche français ou étrangers, des laboratoires publics ou privés. 
1 Design defines the effects of nanoceria at a low dose on soil microbiota and the potentiation of

2 impacts by canola plant

3

4 Mohamed Hamidat ${ }^{1,2}$, Mohamed Barakat ${ }^{1,2}$, Philippe Ortet ${ }^{1,2}$, Corinne Chanéac ${ }^{2,3}$, Jérome Rose ${ }^{2,4}$,

5 Jean-Yves Bottero ${ }^{2,4}$, Thierry Heulin ${ }^{1,2}$, Wafa Achouak ${ }^{1,2}$, and Catherine Santaella*1,2

6

7 1. Laboratory of Microbial Ecology of the Rhizosphere and Extreme Environments (LEMIRE), Aix-

8 Marseille Université, CEA, CNRS, UMR 7265 Biosciences and biotechnology Institute of Aix-

9 Marseille (BIAM), ECCOREV FR 3098, CEA Cadarache, St-Paul-lez-Durance, France

10 2. GDRi iCEINT, international Consortium for the Environmental Implication of Nanotechnology,

11 CNRS-Duke University, F-13545 Aix-en-Provence, France

12 3. Chimie de la Matière Condensée, UMR7574, Collège de France, Université de Jussieu, Paris, F-

1375231 , France

14 4. CNRS, Aix-Marseille Université, IRD, CEREGE UM34, F-13545 Aix en Provence, France

15

16 Author email addresses:

17 Mohamed Hamidat: hamidatmohamed@yahoo.fr

18 Mohamed Barakat: mohamed.barakat@cea.fr

19 Philippe Ortet: philippe.ortet@cea.fr

20 Corinne Chanéac: corinne.chaneac@upmc.fr

21 Jérome Rose: rose@cerege.fr

22 Jean-Yves Bottero: bottero@cerege.fr

23 Thierry Heulin: thierry.heulin@cea;fr

24 Wafa Achouak: wafa.achouak@cea.fr

25 Catherine Santaella: catherine.santaella@cea.fr

26 Corresponding author e-mail: catherine.santaella@cea.fr; tel: 033442257 713; Fax: 033442256648

27

28 


\section{Abstract:}

Soils act as nanoceria sinks via agricultural spreading and surface waters. Canola plants were grown for one month in soil spiked with nanoceria $\left(1 \mathrm{mg} \cdot \mathrm{kg}^{-1}\right)$. To define the role of nanomaterials design on environmental impacts, we studied nanoceria with different sizes (3.5 or $31 \mathrm{~nm})$ and coating (citrate). We measured microbial activities involved in $\mathrm{C}, \mathrm{N}$ and $\mathrm{P}$ cycling in the rhizosphere and unplanted soil. Bacterial community structure was analyzed in unplanted soil, rhizosphere and plant roots by 454-pyrosequencing of the $16 \mathrm{~S}$ rRNA gene. This revealed an impact gradient dependent on nanomaterials design, ranging from decreased microbial enzymatic activities in planted soil to alterations in bacterial community structure in roots. Particle size/aggregation was a key parameter in modulating nanoceria effects on root communities. Citrate coating lowered the impact on microbial enzymatic activities but triggered variability in the bacterial community structure near the plant root. Some nanoceria favored taxa those closest relatives are hydrocarbon-degrading bacteria, and disadvantaged taxa frequently associated in consortia with disease-suppressive activity toward plant pathogens. This work provides a basis to determine outcomes of nanoceria in soil, at a dose close to predicted environmental concentrations, and to design them to minimize these impacts.

\section{Introduction}

Cerium oxide-based nanoparticles (nanoceria) have acquired great interest for their oxygen storage capacities, as well as their optical and catalytic properties. With a global estimated production of 10,000 metric tons/year. ${ }^{1,2}$ nanoceria are used in a variety of industrial sectors including fuel cells, electronic and optical devices, chemical mechanical polishing, exterior paints, and diesel fuel additives. ${ }^{3}$ Some of these applications, such as coatings and paints, are dispersive during use phase. Modeling of the environmental exposure to engineered nanomaterials (ENMs) shows that soils are critical sinks for ENMs. ${ }^{4}$ Keller and Lazareva estimated the global emission of nanoceria in soil to be in the range of 129-1029 metric tons/year. ${ }^{5}$ This elevated value is certainly a concern for the potential risks of ENMs on soil.

Soil microbial communities provide critical ecosystem services including nutrient mineralization and cycling, and contribute to plant growth and health. ${ }^{6}$ ENMs added to soil can have adverse effects on 
57 microorganisms. In microcosms, nanoTiO 2 and nanoZnO $\left(0.5-2{\mathrm{~g} \cdot \mathrm{kg}^{-1}}^{-1}\right.$ soil $)$ reduce microbial biomass 58 and diversity and alter the composition of soil bacterial communities. ${ }^{7} \mathrm{NanoTiO}_{2}$ transiently decreases $59 \mathrm{C}$ mineralization at $1 \mathrm{mg} \cdot \mathrm{kg}^{-1}$ in silty soil rich in organic matter. ${ }^{8}$ Nanosized particles of copper oxide $60(\mathrm{CuO})$ and magnetite $\left(\mathrm{Fe}_{3} \mathrm{O}_{4}\right)\left(<50 \mathrm{~nm}, 1 \mathrm{~g} \cdot \mathrm{kg}^{-1}\right)$ change the hydrolytic activity and bacterial 61 community composition of sandy clay loam soil ${ }^{9}$ Colman et al. demonstrated the reduction of 62 microbial extracellular enzymes and microbial biomass in soil treated with nanosilver $(0.14 \mathrm{mg}$ of $\mathrm{Ag}$ $63 \mathrm{~kg}^{-1}$ soil) in a mesocosm study. ${ }^{10}$ Recently, Ge et al. showed that nanoceria $\left(100 \mathrm{mg} \cdot \mathrm{kg}^{-1}\right)$ alter soil 64 bacterial communities in soil planted with soybean, ${ }^{11}$ although they do not affect soil bacterial 65 communities in unplanted soils. The authors suggest that plants interactively promote nanoceria 66 effects in soil, probably due to belowground carbon changes that result from toxic impact and plant 67 growth decrease.

68 The interactions between plant roots and soil create a narrow zone of soil known as the rhizosphere, 69 which is considered to be one of the most dynamic interfaces on earth. ${ }^{12}$ Numerous biogeochemical 70 processes take place at the plant root-soil interface, which are driven by plant root activity and 71 mediated by soil microorganisms. These processes regulate terrestrial carbon and other cycling 72 elements that sustain plant growth, as well as food, fuel and fiber production. ${ }^{13}$ Understanding how 73 ENMs can interact within the rhizosphere to influence plant and microbial community function and 74 structure is thus crucial for a variety of ecosystem level processes. However, current knowledge on the 75 impact of ENMs on plants and the rhizosphere microbiota is limited.

76 To date, research on the environmental impact of ENMs on soil has largely focused on high 77 concentrations of nanomaterials; by contrast, soil environmental concentrations of nanoceria are 78 predicted ${ }^{14,15}$ within the range of $0.28-1.12 \mathrm{mg} \cdot \mathrm{kg}^{-1}$ and could be even lower $\left(0.09\right.$ to $\left.5.1 \mathrm{mg} \cdot \mathrm{kg}^{-1}\right)$ as 79 predicted in Denmark. ${ }^{16}$ The current study therefore investigates the impact of nanoceria on a soil80 plant-bacteria micro-ecosystem at a concentration of $1 \mathrm{mg} \cdot \mathrm{kg}^{-1}$, which is close to an environmentally 81 relevant nanoceria concentration.

82 Previous studies have highlighted the influence of physicochemical factors such as geometry, coating 83 and surface functional groups on the biological effects of nanoparticles. ${ }^{17,}{ }^{18}$ Nevertheless, the 84 consequences of nanomaterials design still need to be examined in soil. In the case of nanoceria, 
85 particle diameter is critical regarding surface defects, $\mathrm{Ce}^{3+} / \mathrm{Ce}^{4+}$ ratio, and a series of properties such as

$86 \mathrm{O}_{2}$ storage, enzymatic-mimetic activities. ${ }^{19}$ Here, we have evaluated the influence of nanomaterials 87 design on soil bacterial microbiota. The design criteria were focused on particle size and surface charge using pristine or citrate-coated nano- $\mathrm{CeO}_{2}$, with different average particle diameters and 89 surface coating.

90 The microbial activities involved in $\mathrm{C}, \mathrm{N}$ and $\mathrm{P}$ recycling were examined in unplanted soil, and soil 91 planted with canola after one month of exposure to nanoceria. Microbial community structure was analyzed by 454 pyrosequencing of the rrs gene encoding 16SrRNA in planted and unplanted soils, and in plant root systems. Our results reveal a range of gradual impacts dependent on nanomaterials

94 design, from decreased microbial enzymatic activities to alterations in bacterial community structure.

95 More importantly, some nanoceria could exert a selection pressure favoring taxa those closest relatives are aromatic hydrocarbon-degraders, more likely to be resistant to heavy metals and antibiotics, as well as disadvantaged taxa often identified in consortia associated with soil suppressiveness toward plant pathogens. Our results thus provide a basis to determine the potential outcomes of nanoceria in soil, and to design them so as to minimize these impacts, at realistic environmental concentration.

\section{Materials and Methods}

\section{Characteristics of $\mathrm{CeO}_{2}$ nanoparticles}

103 Three different types of commercially available $\mathrm{CeO}_{2}$ nanoparticles (NPs) were added to the soil. Two

104 types were commercial crystallites of cerianite, with sizes of $31 \pm 18 \mathrm{~nm}$, as measured by transmission 105 electron microscopy (TEM) $\left(\mathrm{CeO}_{2}-\mathrm{U}\right.$; Nanograin ${ }^{\circledR}$ Umicore), and $3.5 \pm 0.5 \mathrm{~nm}$ (for $\left.\mathrm{CeO}_{2}-\mathrm{R}\right)$. Citrate106 coated crystallites of $\mathrm{CeO}_{2}-\mathrm{R}$ are used as UV-stabilizer and have a TEM size of $3.9 \pm 1.8 \mathrm{~nm}$ (coated $107 \mathrm{CeO}_{2}$; Nanobyk ${ }^{\circledR}-3810$, Byk). These NPs have been previously described ${ }^{20-22}$ and their characteristics are summarized in Supporting Information (SI) Table $\mathrm{S} 1 . \mathrm{CeO}_{2} \mathrm{NP}$ suspensions were prepared in

109 ultrapure water (UPW; Milli-Q ${ }^{\circledR}$, Millipore). The compared colloidal behavior of $\mathrm{CeO}_{2}-\mathrm{NPs}$ in a 110 natural mineral water (pH 7.9), in interaction with clays (kaolinite), and the same natural water in 111 aquatic mesocosms (organic carbon $2.0 \pm 0.1 \mathrm{mg} . \mathrm{L}^{-1}$ ) is fully described. ${ }^{20-22}$ Briefly, pristine $\mathrm{CeO}_{2}-\mathrm{U}$ 112 tends to rapidly homo-aggregate in UPW (Table S1) and in mineral water (with or without clays), ${ }^{22}$ 
113 and is referred to as pristine $\mathrm{CeO}_{2}$ aggregate in the text. Homo-aggregation in conjunction with hetero114 aggregation with clays was observed for pristine $\mathrm{CeO}_{2}-\mathrm{R}$. Citrate-coated $\mathrm{CeO}_{2}-\mathrm{NPs}_{\text {s }}$ homo- and hetero115 aggregated but this required time-dependent degradation of the coating.

116

117 Soil

118 Topsoil $(0-20 \mathrm{~cm})$ from a clay-loam calcareous soil $(\mathrm{pH} 8.19)$ was collected from an agricultural 119 parcel used for wheat culture in Aix-les-Platanes (France; 433' 45.58' ' N; 05²8'38.78' ' E). The soil 120 was sieved to $4 \mathrm{~mm}$ and stored at room temperature before use. Water $\mathrm{pH}$ of the soil was 8.19 , with $1214.3 \%$ organic matter, 152 mequiv. $\mathrm{kg}^{-1}$ cation exchange capacity, $27.1 \%$ sand, $21.5 \%$ silt, and $18.9 \%$ 122 clay (Gammsol; InVivo Labs, France). Additional soil characteristics are summarized in Table S2.

123 Briefly, $1 \mathrm{~kg}$ of soil was deposited in a thin layer in a plastic bag. A suspension of $\mathrm{CeO}_{2}-\mathrm{NPs}$ was 124 distributed on the surface to achieve $1.0 \mathrm{mg} \cdot \mathrm{kg}^{-1}$ dry soil mass and a humidity of $15 \%(\mathrm{w} / \mathrm{w})$. The 125 control soil was treated identically, but without the addition of NPs. The bag was closed and the soil 126 was homogenized by repeatedly inverting the bag. Soil was sieved again to $4 \mathrm{~mm}$. Sterile syringes (60 $127 \mathrm{~mL}$ ) were used as pots and filled with $70 \mathrm{~g}$ of soil. Three replicates were prepared for each treatment 128 (control, $\mathrm{CeO}_{2}-\mathrm{R}, \mathrm{CeO}_{2}-\mathrm{U}$, and coated $\mathrm{CeO}_{2}$ ).

\section{Plant growth}

131 Canola seeds were planted and plants were grown in phytotrons (SI). Plants were harvested after 30 132 days of growth. Aboveground plant parts were cut and weighed (fresh weight), dried at $60^{\circ} \mathrm{C}$ for three 133 days, and weighed again (dried weight). The root system was retrieved from planted pots and washed 134 repeatedly with sterile UPW. Excess water was blotted on sterile tissue paper and the root system was 135 frozen in liquid $\mathrm{N}_{2}$ and stored at $-80^{\circ} \mathrm{C}$ or alternatively dried at $60^{\circ} \mathrm{C}$ for three days (dry root mass).

136 The entirety of soil from planted pots was considered as rhizosphere, ${ }^{11}$ which was manually cleared 137 from root material, collected, frozen in liquid $\mathrm{N}_{2}$ and stored at $-80^{\circ} \mathrm{C}$. Soil from unplanted pots, 138 considered as bulk soil, was collected in the same way.

140 Enzymatic activity of soil and catalase mimetic activity of cerium oxide nanoparticles 
141 Soil enzyme activities were determined for fresh collected materials. All enzyme activities were

142 performed in triplicate for each treatment. Enzymatic activities are reported as the mean of the three

143 determinations expressed in unit activity per g of dry soil mass. (SI).

144 Catalase mimetic activity of nanoceria was measured by the decrease in the absorbance of $\mathrm{H}_{2} \mathrm{O}_{2}$ at

$145240 \mathrm{~nm}$, using a UV-visible spectrophotometer as described in Singh and Singh. ${ }^{23}$

146

147 DNA extraction and quantification and quantification

148 Total DNA was extracted from $0.5 \mathrm{~g}$ of soil or a root fraction using the FastDNA ${ }^{\mathrm{TM}}$ SPIN Kit for Soil 149 and FastPrep ${ }^{\circledR}-24$ Instrument (MP Biomedicals; Illkirch, France), according to the manufacturer's 150 instructions. DNA concentration was determined by spectrophotometry (NanoVue ${ }^{\mathrm{TM}}$-NV-GE, 151 Healthcare Limited; UK), which measured the absorbance of the samples at 260-280 nm. As a sample 152 control, fragments of the universal rrs gene (encoding 16S rRNA) were amplified by PCR using the 153 universal bacterial primers fD1 (5'-AGAGTTTGATCCTGGCTCAG-3'; positions 8-27 of the rrs 154 gene from E. coli) and S17 (5'-GTTACCTTGTTACGACTT-3'; positions 1492-1509 of the rrs gene 155 from E. coli). The products were analyzed by electrophoresis in 1.5\% (w/v) agarose gels.

156 Total bacteria abundance was measured in the soil by quantitative PCR targeting of rrs. (SI).

158 Sequencing and post-run analysis

159 Barcoded amplicon sequencing processes (bTEFAP () were performed by MR DNA

160 (www.mrdnalab.com, MR DNA; Shallowater, TX) and are described in Dowd et al. ${ }^{24}$ The rrs gene 161 universal eubacterial primers 27Fmod (5'-AGRGTTTGATCMTGGCTCAG-3') and 530R 162 (CCGCNGCNGCTGGCAC) were used to amplify the rss $r r s$ gene regions V1-V3. Further details are 163 provided in SI.

164 Sequence data resulting from the sequencing process were processed using a proprietary analysis 165 pipeline (www.mrdnalab.com, MR DNA; Shallowater, TX). Analysis of high-throughput community 166 sequencing data was performed with QIIME version 1.8. ${ }^{25}$ Further details are provided in SI. A total 167 of 459,709 valid reads and 51,185 OTUs were obtained from the 36 samples through 454 168 pyrosequencing analysis. These OTUs were assigned to 29 different phyla. Each of the 36 
169 communities contained between 3,285 and 35,089 reads, with OTUs ranging from 718 to 8,430 reads.

170 The rarefaction curves (consisting of observed OTUs and the Chao1 estimator) tended to approach the 171 saturation plateau for roots, but not for rhizosphere and bulk soil samples (Fig. 1a). Good's coverage 172 estimations revealed that $86-95 \%$ of the species were obtained in root samples, whereas $82-88 \%$ of the 173 species were determined in soil samples. Although no OTU-level rarefaction curves plateaued under 174 the current sequencing depth, the Shannon diversity indices reached stable values (Figure S1b). This 175 suggests that most of the microbial dominant diversity has been addressed in this data set. ${ }^{26}$

176

\section{Statistical Analyses}

178 The variables were checked for normality (Shapiro-Wilk test) and homoscedasticity (Levene test). The 179 significance of results was examined by one-way analysis of variance (ANOVA) followed by post-hoc 180 tests (Student-Newman-Keul test). Pearson correlation coefficients were calculated to measure the 181 strength of the association between microbial enzymatic activities. These analyses were performed in 182 STATGRAPHICS Centurion XVI.II. P $<0.05$ was considered to be statistically significant.

183 For data that were not normally distributed, permutations (PERMANOVA, 999 permutations) and 184 other non-parametric tests (non-parametric t-tests, Kruskal-Wallis test) were performed in $\mathrm{R}$ 185 (http://www.R-project.org) or STATGRAPHICS. VEGAN's 'adonis' function was used to perform PERMANOVA with constrain permutations of nested factor ("strata" parameters). For multiple testing, P-values were corrected to Q-values using the Benjamini-Hochberg False Discovery Rate

188 (FDR). ${ }^{27}$ We selected a non-stringent Q-value set at 0.25 to avoid missing any important leads 189 (http://www.biostathandbook.com/multiplecomparisons.html). Parametric and non-parametric 190 statistics were implemented to identify OTU taxonomic groups (community modules) and individual 191 OTUs (community members) that differ quantitatively between treatments within a compartment. ${ }^{28}$ 192 For analyses of OTU taxonomic groups, we prepared abundance matrices at the phylum rank 193 containing the sum of OTU abundances for all OTUs per given taxon. Statistical comparisons of 194 taxonomic groups were made for relative abundance using the Kruskal-Wallis test. OTU richness in 195 soil is the result of a large number of low-count OTUs. ${ }^{28}$ For individual OTU statistics, the follow-up 196 analysis focused on the abundant community members (ACM $)^{28}$ defined here as OTUs that account 
197 for $0.1 \%$ of the total observation (sequence) count of an OTU among the 36 treatments $(260,175$

198 sequences), representing $56.6 \%$ of the initial total count. The ACM matrix, including bulk soil, 199 rhizosphere, and root samples, was rarefied at 1,067 reads and was represented by 99 bacterial OTUs 200 and 38,412 observations. Statistical analysis (ANOVA) was applied to count of bacterial taxa at 201 multiple taxonomic levels.

202

203 Results

204 Nanoceria affect the microbial enzyme activities in the rhizosphere

205 We measured the activity of hydrolase and oxidoreductase soil enzymes known to be involved in the 206 degradation of a range of substrates that are common constituents of organic matter. ${ }^{29}$ Keystone 207 enzymes were selected to represent carbon cycling, such as ß-glucosidase (polysaccharides, e.g. 208 cellulose), peroxidase and phenoloxidase (aromatic carbon, e.g. lignin), as well as nitrogen cycling, 209 including endoprotease (peptide, e.g. protein) and organic $\mathrm{P}$ such as acid and alkaline phosphatases (P 210 monoesters). We also measured catalase activity related to aerobic metabolism. Table 1 summarizes 211 the enzymatic activities of $\mathrm{C}, \mathrm{N}$, and $\mathrm{P}$ recycling in bulk soil and rhizosphere.

212 In bulk soil, the three types of $\mathrm{CeO}_{2}-\mathrm{NPs}$ did not alter any of the enzymatic activities tested (as 213 compared to controls), with the exception of bare $\mathrm{CeO}_{2}-\mathrm{U}$ NPs, which significantly decreased catalase

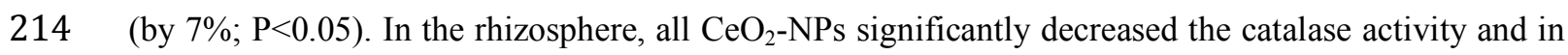
215 a similar extent as compared to controls (by $19 \pm 8 \%, 17 \pm 3 \%$ and $22 \pm 2 \%$ for pristine $\mathrm{CeO}_{2}-\mathrm{R}, \mathrm{CeO}_{2}-\mathrm{U}$ 216 and coated $\mathrm{CeO}_{2}$, respectively).

217 In the rhizosphere, small-size and aggregated pristine $\mathrm{CeO}_{2}-\mathrm{NPs}$ both decreased $\beta$-glucosidase and 218 alkaline phosphatase activities with similar magnitudes (approximately 19-20\%). The three nanoceria 219 types did not affect any of the other assayed enzyme activities (i.e. protease, acid phosphatase, 220 peroxidase and phenoloxidase). Some enzymatic activities, such as catalase (for all NPs) and alkaline 221 phosphatase (for pristine $\mathrm{CeO}_{2}-\mathrm{R}$ and $\mathrm{CeO}_{2}-\mathrm{U}$ ), were substantially decreased in the rhizosphere to 222 levels observed in bulk soil. Coated $\mathrm{CeO}_{2}$-NPs displayed the lowest effects on enzymatic activities, 223 which included decreased catalase activity in the rhizosphere and the absence of any effect on the 224 activity of the other assayed enzymes. 
225 Both small-size $\mathrm{CeO}_{2}-\mathrm{R}$ and coated $\mathrm{CeO}_{2}$ exhibited catalase mimetic activity, whereas large-size bare $226 \mathrm{CeO}_{2}-\mathrm{U}$ did not significantly reduce hydrogen peroxide activity (Fig. S2).

\section{Nanoceria do not impact bacterial abundance or richness in the three compartments}

229 Nanoceria did not significantly decrease the microbial biomass based on extractable DNA $(\mathrm{P}>0.05)$ in 230 soil or the bacterial abundance ( $\mathrm{P}>0.05)$, as revealed by the quantitative PCR data (Table S3).

231 We used alpha diversity to describe the total diversity of OTUs within the different treatment 232 communities $\left(\mathrm{CeO}_{2}-\mathrm{R}, \mathrm{CeO}_{2}-\mathrm{U}\right.$, coated $\mathrm{CeO}_{2}$ and control) among the three compartments (bulk soil, 233 rhizosphere and root). Alpha diversity was summarized, taking into account measures of richness 234 based on qualitative Chaol and quantitative Shannon estimators, as well as phylogeny-based measures 235 such as Faith's PD. Figure S2 shows rarefaction curves for OTUs based on observed OTUs and 236 distance box plots for Chao1, Shannon and PD estimators. The Chao1, Shannon index, and PD 237 measures revealed that none of the $\mathrm{CeO}_{2} \mathrm{NP}$ treatments affected the alpha diversity of the microbiome 238 (as compared to the controls) in the root compartment, the rhizosphere or bulk soil, when controlling 239 for compartment status. A significant increase was observed for PD in the bulk soil microbiota of the $240 \mathrm{CeO}_{2}-\mathrm{U}$ treatment as compared to $\mathrm{CeO}_{2}-\mathrm{R}$ (Fig. 2; $\mathrm{P}=0.014$ and $\mathrm{P}=0.024$ in observed OTUs and $\mathrm{PD}$, 241 non-parametric two-sample t test).

\section{Nanoceria greatly affect the root microbiota}

244 In order to identify nanoceria treatments associated with compositional dissimilarity in microbiota, we 245 examined the $\beta$-diversity, which is a measure of diversity between samples. Principal coordinates 246 analysis (PCoA; Fig. 1a) and PERMANOVA analysis of unweighted UniFrac distances revealed 247 clustering of microbial communities based on the soil compartment factor $(\mathrm{P}=0.0001)$, but not on nanoceria treatment $(\mathrm{P}=0.32)$. Taking into account the relative abundance of organisms, $\mathrm{PCoA}$ of

249 weighted UniFrac (Fig. 1b) and Bray-Curtis (Fig. 1c) distances showed clustering based on 250 compartment $(\mathrm{P}=0.0001$ and $\mathrm{P}=0.001$, respectively; PERMANOVA) but not on treatment $(\mathrm{P}=0.15$ and $251 \mathrm{P}=0.16$, respectively). Jackknifed PCoA analysis of unweighted and weighted UniFrac and Bray252 Curtis distance metrics resulted in similar conclusions (Fig. S3). 
253 Since the "compartment" factor appeared as a main variable causing change in the bacterial

254 microbiota, we assessed the effect of nanoceria treatment within the compartment subgroups.

255 Constrained permutations within compartments showed clustering of microbiota based on treatment

256 for the weighted UniFrac distance $(\mathrm{P}=0.009)$ and Bray-Curtis distance $(\mathrm{P}=0.0129)$ but not the

257 unweighted UniFrac distance $(\mathrm{P}=0.08)$.

258 PERMANOVA analysis of UniFrac distance matrices revealed that $\mathrm{CeO}_{2}-\mathrm{U}$ induced significant 259 differences in roots, when controlling for compartment status (Table S4). Taking into account 260 compartment status, $\mathrm{CeO}_{2}-\mathrm{U}$ was observed to induce significant changes in root bacterial microbiota, 261 as compared to both the control $(\mathrm{P}=0.002)$ and $\mathrm{CeO}_{2}-\mathrm{R}(\mathrm{P}=0.005)$, based on weighted UniFrac 262 distances., and significant changes in root bacterial microbiota, in comparison to the control $(\mathrm{P}=0.042)$ 263 and coated $\mathrm{CeO}_{2}(\mathrm{P}=0.022)$, when using unweighted UniFrac distances (Table S4). Regarding the 264 analysis of the weighted or unweighted UniFrac distances, nanoceria treatments did not affect the 265 dominant microbiota in bulk soil or in the rhizosphere (as compared to the control; data not shown). 266 As the rarefaction curve did not plateau, we may miss differences that exist in the rare biosphere, 267 which is currently not quantifiable. ${ }^{28}$

268

269 Nanoceria significantly modulate the relative abundance of bacterial taxa in the rhizosphere

270 Figure 2 displays the bacterial microbiota composition by phylum in the root compartment. Statistical 271 analysis (Kruskal-Wallis) exposed significant differences in the microbiota composition at the phylum 272 level for the different treatments, when controlling for compartment status (Table S5). In roots, 273 significant differences in the relative abundance of bacterial taxa clustered $\mathrm{CeO}_{2}-\mathrm{U}$ from control 274 treatment. The abundance of the phyla Fibrobacteres, Chloroflexi and Proteobacteria significantly 275 increased in the $\mathrm{CeO}_{2}-\mathrm{U}$ treatment $(0.16 \%, 1.2 \%$ and $64.1 \%$, respectively) in comparison to the 276 control $(0.02 \%, 0.66 \%$ and $42.8 \%$, respectively), whereas the abundance of the Actinobacteria phylum 277 decreased in the $\mathrm{CeO}_{2}-\mathrm{U}$ treatment (6.3\%), as compared to the control (37.4\%).

278 In the root compartment, three phyla differentiated the bacterial microbiota of $\mathrm{CeO}_{2}-\mathrm{U}$ as compared to $279 \mathrm{CeO}_{2}-\mathrm{R}$, with a decrease in Actinobacteria (from $21 \%$ to $6.3 \%, \mathrm{P}=0.049, \mathrm{FDR}=0.23$ ), an increase in 
280

281

282

283

284

285

286

287

288

289

290

291

292

293

294

295

296

297

298

299

300

301

302

303

304

Chloroflexi (0.63-1.2\%, $\mathrm{P}=0.049)$ and Proteobacteria $(54.6-64.1 \%, \mathrm{P}=0.049)$, and an increase in the FDR threshold (0.23).

The phylum Armatimonadetes and candidate phylum TM7 were significantly decreased in the $\mathrm{CeO}_{2}-\mathrm{R}$ treatment as compared to the control $(0.16-0.01 \%, \mathrm{P}=0.046$ and $0.75-0.32 \%, \mathrm{P}=0.049$, respectively), whereas a compensatory increase was observed in Proteobacteria and Verrumicrobia (42.7-54.6\%, $\mathrm{P}=0.049$ and $1.6-2.3 \%, \mathrm{P}=0.049, \mathrm{FDR}=0.17)$. No significant differences were found in bulk soil or in the rhizosphere compartment ( $\mathrm{P}$-value $<0.05$ although $\mathrm{Q}$ value $>0.25$, data not shown).

OTU richness in soil is the result of a large number of low-count OTUs. ${ }^{28}$ Follow-up analysis focused on the community members that accounted for more than $0.1 \%$ of the total OTU counts in the matrix rarefied to 1,067 sequences. Certainly, conclusions based on the abundant community members do not account for the contribution of low-abundance taxa. These rare biosphere taxa have important ecological roles, as reservoirs of genetic and functional diversity, in the resilience of ecosystems. ${ }^{30}$

Statistical analysis (one-way ANOVA) revealed significant differences in the relative abundance of bacterial taxa at multiple taxonomic levels in the root compartment (Table S6). Among all treatments, some OTUs discriminated $\mathrm{CeO}_{2}-\mathrm{U}$ from controls and $\mathrm{CeO}_{2}-\mathrm{R}$ treatment.

In $\mathrm{CeO}_{2}-\mathrm{U}$ vs. control, microbiota data revealed a severe decrease in the mean relative abundance of Janthinobacterium, Kribbella, Micrococcaceae, Streptomyces and Pseudoxanthomonas, and an increase in Acidovorax, Pelomonas and Methylibium. In $\mathrm{CeO}_{2}-\mathrm{U}$ vs. $\mathrm{CeO}_{2}-\mathrm{R}$, mean relative abundances were reduced for Janthinobacterium, Micrococcaceae and Variovorax, whereas they were increased in Acidovorax and Methylibium.

Acidovorax and Pelomonas were barely detected in bulk soil $(<0.001 \%)$ and the rhizosphere $(0.006 \%)^{31}$, although they were highly enriched in the root compartment of the $\mathrm{CeO}_{2}-\mathrm{U}$ treatment. In $\mathrm{CeO}_{2}-\mathrm{U}$ treatment vs. control, the OTUs affiliated to Acidovorax accounted for $5.65 \%$ (vs. $0.22 \%$ ), Pelomonas for $7.65 \%$ (vs. 1,69\%) and Methylibium for 38133\% (vs 7.6\%). Methylibium was the most abundant genus that could discriminate $\mathrm{CeO}_{2}-\mathrm{U}$ treatment from the control and $\mathrm{CeO}_{2}-\mathrm{R}$, with an $80-$ fold enrichment from the bulk soil compartment to the root compartment.

\section{Addition of nanoceria to soil at $1 \mathrm{mg} . \mathrm{kg}^{-1}$ does not impact plant growth}


308 Canola plants were grown from seeds for four weeks in a clay-loam calcareous soil enhanced with 309 pristine $\left(\mathrm{CeO}_{2}-\mathrm{R}\right.$ or $\left.\mathrm{CeO}_{2}-\mathrm{U}\right)$ or citrate-coated $\mathrm{CeO}_{2}-\mathrm{NPs}$ at a concentration of $1 \mathrm{mg} / \mathrm{kg}$ (dry soil mass). 310 Plant growth was monitored by measuring the dry biomasses of below and aboveground plant parts 311 (Fig. S5). None of the $\mathrm{CeO}_{2}$ NP treatments affected plant growth (one-way ANOVA; $\mathrm{P}=0.85$ for 312 shoots and $\mathrm{P}=0.55$ for roots).

\section{Discussion}

Nanoceria trigger functional differences that do not correlate with changes in bacterial microbiota composition

317 Soil enzymatic activities are recognized sensors of natural and anthropogenic disturbances occurring in the soil ecosystem. They play a crucial role in nutrient cycling and in organic matter decomposition. Furthermore, any dysfunction in the enzymatic activity of soils may disturb the biological equilibrium of soil, which may have ecological and economic consequences. ${ }^{32}$

321 In the current study, the addition of $\mathrm{CeO}_{2}-\mathrm{NPs}$ to soil was found to lower several hydrolytic and 322 oxidoreductive soil microbial activities. The three different NPs reduced catalase activity in the 323 rhizosphere, with the largest pristine $\mathrm{CeO}_{2}-\mathrm{U}$ NPs extending this effect into bulk soil. Catalase activity 324 may be related to the metabolic activity of aerobic organisms and has been used as an indicator of soil

325 fertility. ${ }^{33}$ The decrease in catalase activity resulting from the NP treatments suggests an inhibition of 326 aerobic bacterial microbiota. The intrinsic catalase mimetic activity of $\mathrm{CeO}_{2}-\mathrm{R}$ and coated $\mathrm{CeO}_{2}-\mathrm{NPs}$ 327 could minimize the decrease in the measured enzymatic activity. In the rhizosphere, as compared to 328 controls, pristine small size $\mathrm{CeO}_{2}-\mathrm{R}$ and large size $\mathrm{CeO}_{2}-\mathrm{U}$ decreased the $\beta$-glucosidase activity, which 329 is key in the last limiting step of cellulose degradation ( $\mathrm{C}$ cycle), and reduced the alkaline phosphatase 330 activity, which is crucial in organic $\mathrm{P}$ transformation.

332 Based on the quantitative Shannon and qualitative Chao1 richness estimators and the divergence333 based $\mathrm{PD}$ values did not reflect any impact from $\mathrm{CeO}_{2} \mathrm{NP}$ treatments on bacterial microbiota richness 334 in the bulk soil and rhizosphere compartments, as compared to the controls. Based on UniFrac metrics, 335 which calculate a distance measure between communities using phylogenetic information, ${ }^{34}$ the 
336 diversities observed in bulk soil and the rhizosphere were comparable between NP treatments and 337 controls. Based on the quantification of 16S rRNA gene copies (Table S3), NP treatments did not alter 338 the size of bacterial communities. Many studies have shown some impact of NPs on soil enzymatic 339 activities, often on microbial biomass and diversity. For example, Wang et al. demonstrated that soil 340 catalase activity was significantly decreased by nano- $\mathrm{Fe}_{3} \mathrm{O}_{4}$ as well as urease activity. ${ }^{35} \mathrm{Fe}_{2} \mathrm{O}_{3}$ and $341 \mathrm{ZnO}$ NPs can effectively maintain various soil microbiological processes at $100 \mathrm{mg} \cdot \mathrm{kg}^{-1}$, however 342 higher concentrations (e.g. 500-1000 mg. $1 \mathrm{~kg}^{-1}$ ) have negative impacts on soil ecology. ${ }^{36}$ Accordingly, 343 soil protease, catalase and peroxidase activities were inhibited in the presence of the $\mathrm{TiO}_{2}$ and $\mathrm{ZnO}$ 344 nanoparticles. ${ }^{37}$ Moreover, $\mathrm{CuO}$ NPs added to a sandy loam (at 1 and $10 \mathrm{mg} \cdot \mathrm{kg}^{-1}$ ) had a strong effect 345 on bacterial hydrolytic activity. ${ }^{9}$ These studies were conducted on a time-scale comparable ${ }^{35,36}$ or on 346 much longer periods of time ${ }^{9,37}$, however at higher doses of NPs. In our study, enzymatic activity 347 changes observed in bulk soil and the rhizosphere treated with NPs (in the presence of a low dose of $348 \mathrm{CeO}_{2}$-NPs) did not correlate with a modification in bacterial community structure or size. Rather, 349 these changes were linked to an inhibition of their enzymatic activities (potentially in aerobic 350 bacteria), reduction of bacterial activity (that is undetected using a DNA-based approach), or to 351 changes in microbial communities other than bacteria.

Canola potentiates the nanoceria impact on microbial activity and community structure

354 Measuring the activity of several enzymes in soil is a suitable method to estimate the overall microbial 355 activity and its response to prevalent pollution. ${ }^{38}$ Our results indicate that catalase, $\beta$-glucosidase and 356 alkaline phosphatase activities were inhibited by pristine nanoceria at $1 \mathrm{mg} \cdot \mathrm{kg}^{-1}$. These activities were 357 gradually impacted in terms of magnitude and type of the enzymes affected, progressing from the bulk 358 soil to the rhizosphere.

359 Similarly, we found a significant impact of pristine $\mathrm{CeO}_{2}-\mathrm{U}$ on the selection of the microbiota in the 360 root compartment, based on the analysis of UniFrac distance metrics, phyla, and OTUs. Nanoceria did 361 not significantly affect the microbiota of bulk soil or the rhizosphere, in comparison to controls. Thus, 362 based on soil enzyme activities and microbial community composition, we have uncovered a 
363 'nanoceria impact gradient' progressing from bulk soil to the root-soil interface, indicating that the 364 plant potentiates the impact of these NPs in soil.

365 Terminal restriction fragment length polymorphism (T-RFLP) and PhyloChip analyses were recently 366 used to determine that nano- $\mathrm{CeO}_{2}-\mathrm{NPs}\left(100 \mathrm{mg} \cdot \mathrm{kg}^{-1}\right)$ do not affect soil bacterial communities in 367 unplanted soils, although they do trigger shifts in soybean rhizosphere communities. ${ }^{11}$ No OTUs were 368 significantly correlated with nano- $\mathrm{CeO}_{2}$ treatment, and the authors interpreted these results in terms of 369 an indirect effect of nano- $\mathrm{CeO}_{2}$ on plant growth. Although the study did not quantify or analyze plant 370 root exudates, the authors suggested that the exudation could be reduced, due to the stunted growth of 371 plants exposed to $100 \mathrm{mg} \cdot \mathrm{kg}^{-1}$ of nano- $\mathrm{CeO}_{2}$ ) or modified in composition, due to an abiotic stress of $372 \mathrm{CeO}_{2}$-NPs on plant roots. However, in our conditions, canola growth was not reduced based on the 373 above and belowground biomasses. We therefore conclude that the effect of $\mathrm{CeO}_{2}-\mathrm{NPs}$ on plant root 374 microbiota is not only mediated by an effect on the plant, but that it could also originate from a direct 375 effect on bacteria. Pelletier and al. showed a size-dependent effect on the growth inhibition of 376 Escherichia coli by nanoceria. ${ }^{39}$

378 Nanoceria generate microbiota with double-edged potential significance to plant and environmental 379 health

380 Our use of quantitative PCR and alpha diversity estimators indicates that the three nanoceria examined 381 in this study did not alter biomass or bacterial diversity, as compared to the controls. However, pristine 382 large-size $\mathrm{CeO}_{2}-\mathrm{U}$ NPs significantly affected the community structure (in comparison to controls), as 383 seen in the analysis of UniFrac distance metrics. $\mathrm{CeO}_{2}-\mathrm{U}$ treatment resulted in an increase in 384 Burkholderiales, in the Comamonadaceae family, especially in Acidovorax (5.65\%), Pelomonas, and 385 Methylibium genera. (Table S6). In the root compartment, the total abundance of these OTUs reached $38668.06 \%$ in the abundant community members for $\mathrm{CeO}_{2}-\mathrm{U}$ treatment vs $9.51 \%$ in the controls (Table 387 S6). Alternatively to Ribosomal Database Project (RDP) classifier pipeline, OTU sequences can be 388 resolved using NCBI's Taxonomy. Based on BLAST taxonomic assignment, the closest relatives to 389 these OTUs were Acidovorax radicis N35, Pelomonas saccharophila, Methylibium petroleiphilum $390 \quad P M 1$ and Methylibium fulvum (reclassified as Rhizobacter fulvum). ${ }^{47}$ All these bacteria are reported as 
391 degraders of polycyclic aromatic hydrocarbons (PAHs) in soil. ${ }^{48-55}$ Triggering the rise of microbial 392 genera that potentially degrade PAHs can be advantageous for remediation of hydrocarbon in soils. 393 However, hydrocarbon-degrading properties in bacteria can come with heavy metal tolerance, as well 394 as resistance to antibiotics and multidrug resistance ${ }^{40-42}$, potentially in Methylibium and Acidovorax 395 genera. ${ }^{43,44}$ A functional gene analysis is needed to demonstrate this hypothetical trend. Yergeau et al. 396 identified Methylibium in a microbial community active in the rhizosphere of willow planted in HAP397 contaminated soils. ${ }^{45}$ They show that genes related to hydrocarbon degradation together with antibiotic 398 resistance were more expressed in the HAP-contaminated rhizosphere. This underscores the need for 399 caution when disseminating ENMs that could exert a selection pressure conducive of microbial 400 blooms potentially resistant to heavy metals and antibiotics.

$401 \mathrm{CeO}_{2}-\mathrm{U}$ NPs significantly decreased the abundance of OTUs in Actinobacteria (including the 402 Actinosynnemataceae and Micrococcaceae families and Streptomyces), Gammaproteobacteria and 403 Betaproteobacteria within the Burkholderiales (Janthinobacterium), and Xanthomonadales 404 (Pseudoxanthomonas) families (Table S6). These taxa are have been identified as the most dynamic 405 taxa associated with disease suppression in soil. ${ }^{46}$ Among the ACM, Janthinobacterium 406 (Oxalobacteraceae) was enriched in the root compartment of control plants (12.4\%), but inhibited in 407 the $\mathrm{CeO}_{2}-\mathrm{U}$ treatments (3.0\%). A significant decrease in the Streptomyces and Pseudoxanthomonas 408 genera was observed in the root compartment of the $\mathrm{CeO}_{2}-\mathrm{U}$ treatment $(0.7 \%$ and $0.6 \%$, respectively), 409 in comparison to the control (6.1 and 4.6\%, respectively). Janthinobacterium, Streptomyces and 410 Xanthomonadaceae are identified in consortia associated with soil suppressiveness against plant 411 pathogens. ${ }^{47-50}$ Importantly, disease suppressiveness of soil can help to reduce pesticide use. 412 Janthinobacterium and Xanthomonadaceae are both dominant taxa that exhibit a positive association 413 with plant shoot weights in wheat, ${ }^{51}$ peach tree ${ }^{50}$ and rice, ${ }^{52}$ suggesting a beneficial role for these 414 bacterial groups. Thus, $\mathrm{CeO}_{2}-\mathrm{U}$ treatment mostly affected families or genera that are beneficial to 415 plant health and growth. 
419 In this study, we aimed to examine how particle size or coating could modulate the impact of NPs on

420 microbiota activity and composition in bulk soil, rhizosphere, and root compartments.

421 This work revealed a gradient effect for the impact on microbial activity and community structure, 422 according to the design of nanoceria. Constrained PERMANOVA of the unweighted UniFrac distance 423 showed significant differences in coated $\mathrm{CeO}_{2}-\mathrm{NPs}$ vs $\mathrm{CeO}_{2}-\mathrm{R}$, and in $\mathrm{CeO}_{2}-\mathrm{R}$ vs $\mathrm{CeO}_{2}-\mathrm{U}$, in the 424 rhizosphere (Table S4). These results demonstrate that particle size and coating trigger differences in 425 the microbiomes. However, even if some phyla or OTUs were able to significantly discriminate 426 between these treatments (P-value $<0.05$ ), the Q-values surpassed the FDR 0.25 threshold (data not 427 shown).

428 Pristine aggregates of $\mathrm{CeO}_{2}-\mathrm{U}$ NPs significantly altered the microbiota composition in the root 429 compartment in comparison to controls, $\mathrm{CeO}_{2}-\mathrm{R}$ and coated $\mathrm{CeO}_{2}$, whereas pristine small $\mathrm{CeO}_{2}-\mathrm{R}$ NPs 430 did not show any impact (in comparison to the controls). Thus, particle size appears to be a key 431 parameter in modulating the fate of $\mathrm{CeO}_{2}$-NPs in the rhizosphere, as well as access to the soil-root 432 interface. This conclusion needs to be confirmed with other NPs before being extended.

433 The mobility of $\mathrm{CeO}_{2}$-NPs in soil depends on the soil organic matter content, and on the surface 434 coating of the NPs. Recent work has shown that alginate-coated NPs have higher mobility than 435 uncoated NPs, in sandy loam soil with very low organic matter content. ${ }^{53}$ However, surface coating 436 decreases the NP mobility in soil solution, when the soil is enriched in organic matter. Exudation of 437 small organic molecules increases the concentration of organic ligands in the vicinity of the root 438 system. The competition of these organic molecules for adsorption onto the cerium surface is certainly 439 a factor that will increase the mobility of uncoated nanomaterials.

440 Water moves through the soil to the plant root and then to the transpiring leaves along pressure 441 gradients: these comprise suction (negative pressure) gradients in the soil, and diffusion pressure 442 deficit gradients in the plant. ${ }^{54}$ It can therefore be assumed that NP diffusion in soil originates from 443 these pressure gradients. One recent study of porosity and hydraulic conductivity of the rhizosphere 444 has shown that bulk soil is better at retaining water than the rhizosphere. ${ }^{55}$ Soils influenced by roots 445 (rhizosphere soil) are less porous due to increased aggregation, in comparison to bulk soil. Based on 446 size exclusion, it is likely that large-size and aggregated $\mathrm{CeO}_{2}-\mathrm{U}$ NPs can diffuse more easily at the 
447 root interface, whereas smaller size NPs could be hindered in their interaction with sites inside the 448 microporosity zone. ${ }^{56}$

449 As stated above, pristine aggregates of $\mathrm{CeO}_{2}-\mathrm{U}$ enabled the selection of bacterial genera those 450 members are identified as PAH degraders. Bacteria that degrade PAHs utilize an efficient oxidase to 451 promote the first step of hydrocarbon conversion, producing reactive oxygen species. Potent 452 mechanisms for reducing oxidative stress are thus required in all aerobic microorganisms that produce 453 oxygenase-type enzymes to metabolize pollutants. ${ }^{57} \mathrm{CeO}_{2}$-NPs (IV) display a catalase mimetic activity 454 that is resistant to phosphate anions, $\mathrm{pH}$ changes and composition of cell culture media. ${ }^{23}$ As indicated 455 by XANES, ${ }^{20-22}$ the nanoceria used in this study have a (IV) oxidation state. $\mathrm{CeO}_{2}-\mathrm{R}$ and coated $\mathrm{CeO}_{2}$ 456 exhibited catalase mimetic activity in vitro, which are likely to be retained in soil. Among the 457 nanoceria that we examined, only $\mathrm{CeO}_{2}-\mathrm{U}$, which lacks catalase activity, promoted the selection of 458 genera comprising hydrocarbon degraders potentially endowed with resistance to oxidative stress. 459 Many previous studies have shown that the catalase activity of nano- $\mathrm{CeO}_{2}$ eases the impact on 460 organisms. $^{58-61}$

461 Pristine small-size $\mathrm{CeO}_{2}-\mathrm{R}$ and aggregates of $\mathrm{CeO}_{2}-\mathrm{U}$, which display comparable surface charges, had 462 similar effects on the hydrolytic enzymes tested. The two pristine NPs both decreased B-glucosidase 463 and alkaline phosphatase enzyme activities, suggesting comparable interactions between the two types 464 of pristine NPs and the exocellular enzymes investigated (independent of particle size and initial 465 aggregation state). Conversely, citrate-coated $\mathrm{CeO}_{2}$ particles did not affect these activities.

466 Compositional differences in microbial communities were not responsible for the observed functional 467 differences of $\mathrm{CeO}_{2}$-NPs in the rhizosphere. Charge interactions could thus explain the inhibition of 468 these hydrolytic exocellular enzymes. Indeed, $\mathrm{CeO}_{2}$-NPs must be in direct contact with cells in order 469 to display toxicity, via the reduction of $\mathrm{Ce}(\mathrm{IV})$ to $\mathrm{Ce}(\mathrm{III}){ }^{22,}{ }^{62}$ Citrate coating tends to decrease the 470 interaction of NPs with cells, as well as the Ce reduction kinetics. ${ }^{63}$ However, positively charged $471 \mathrm{CeO}_{2}$-NPs become negatively charged in soil, due to the adsorption of phosphate ions or citrate (and 472 potentially carbonate ions, in the case of an alkaline soil). ${ }^{64}$ These new negatively charged sites at the 473 surface can promote hetero-aggregation of $\mathrm{CeO}_{2}-\mathrm{NPs}$ with natural colloids, such as clays or metallic 474 oxides. Citrate-stabilized and bare Ag-NPs showed similar sorption to silt particles in low-carbon soil, 
475 suggesting that the surface charge does not control Ag-NP sorption to silt. ${ }^{65}$ Nevertheless, the citrate

476 ligand is capable of forming a chelate through more than one coordinating group. Therefore, this

477 coating could act as a cross-linker to associate $\mathrm{CeO}_{2}$-NPs with colloids in a different way than the

478 negative surface charges promoted by phosphate or carbonate ions.

479 Citrate-coated NPs tend to have a low effect on enzyme activities and on the bacterial community 480 structure. However, this lack of an impact may be misleading in the vicinity of the root, due to the

481 high variability in most of the parameters measured in the rhizosphere and the root compartment 482 (biomass in the rhizosphere, UniFrac distance metrics and relative abundance of phyla in the root 483 compartment) for citrate-coated $\mathrm{CeO}_{2}$-NP treatment (Table S3, Fig. 1, Fig. S4), which precluded 484 significant differences with other treatments. Plant roots release small organic acids that can 485 remobilize organic compounds, such as HAPs by desorption from soil aggregates. ${ }^{66}$ Citrate coating of 486 NPs can readily exchanges with dissolved organic matter (DOM) in soil. ${ }^{67}$ We hypothesize that a 487 progressive and random release/exchange of the coating with DOM near the root, allows NPs to 488 interact with different colloid fractions, ions or cells, which triggers a variable behavior in the 489 rhizosphere and root compartment. We hypothesize that a progressive and random release/exchange of 490 the coating, near the root, allows NPs to interact with different colloid fractions, ions or cells, which 491 triggers a variable behavior in the rhizosphere and root compartment.

492 Altogether, our results show that nanoceria reduce microbial enzymatic activities and alter the 493 bacterial community structure, and that these effects spatially increase along a gradient progressing 494 from bulk soil to the root compartment. The design of nanoceria, including particle aggregation and 495 coating, clearly determines the amplitude of this impact. The primary effect occurred for aggregated 496 pristine nanoceria, which were deprived of catalase activity. Contamination of soil with pristine 497 aggregates of nanoceria conferred a selective advantage to genera whose common members are 498 hydrocarbon-degrading bacteria, which are potentially more resistant to oxidative stress, heavy metals 499 and antibiotics. On the other hand, several families and genera, whose membres can be involved in 500 disease-suppressive activity toward plant pathogens, were inhibited in the root compartment of canola.

501 The finding that these effects occurred at the lowest dose ever tested in soil $\left(1 \mathrm{mg} \cdot \mathrm{kg}^{-1}\right)$ is of particular 502 concern, and invites further research in order to identify the resilience of the ecosystem. Nevertheless, 
503 when 4-nm sized $\mathrm{CeO}_{2}$-NPs were tested, the impact of nanoceria was limited to enzymatic activities.

504 This shows that nanoceria can be designed to ease the impact on soil microorganisms.

505

\section{Acknowledgments}

507 The authors thank the CNRS for financial support through funding the GDRi-iCEINT, and the French 508 ANR for funding the ANR-10-NANO-0006/MESONNET project. Author M. Hamidat received a 509 grant from the Labex Serenade (ANR-11-LABX-0064) funded by the "Investissements d'Avenir" 510 French Government program of the French National Research Agency (ANR) through the A*MIDEX 511 project (ANR-11-IDEX-0001-02).

512

\section{Supporting Information}

514 Supporting Information includes detailed protocols of enzymatic activity experiments, sequencing and 515 post-run analyses, catalase mimetic activity of nanoceria, microbial diversity (PCoA plots and 516 composition at the phylum level), plant biomass, physicochemical properties of the nanoceria and oil 517 used in these experiments, and bacterial biomass. This material is available free of charge via the 518 internet at http://pubs.acs.org.

519

\section{References}

521 1. Types and Uses of Nanomaterials, Including Safety Aspects; Commission Staff Working 522 Paper; European Commission: Brussels, 2012; eur-lex.europa.eu/legal523 content/EN/TXT/PDF/?uri=CELEX:52012SC0288\&from=EN.

524 2. The Global Market for Nanomaterials 2002-2016: Production volumes, revenues and end user 525 markets demand; Report; Future Markets, Inc; Dublin, 2012; 526 researchandmarkets.com/reports/2019506/.

527 3. Collin, B.; Auffan, M.; Johnson, A. C.; Kaur, I.; Keller, A. A.; Lazareva, A.; Lead, J. R.; Ma, 528 X. M.; Merrifield, R. C.; Svendsen, C.; White, J. C.; Unrine, J. M., Environmental release, fate and 529 ecotoxicological effects of manufactured ceria nanomaterials. Environ. Sci. Nano 2014, 1 (6), 533-548; 530 DOI 10.1039/c4en00149d. 
531 4. Gottschalk, F.; Sonderer, T.; Scholz, R. W.; Nowack, B., Modeled environmental 532 concentrations of engineered nanomaterials ( $\mathrm{TiO}(2), \mathrm{ZnO}, \mathrm{Ag}, \mathrm{CNT}$, Fullerenes) for different regions. 533 Environ. Sci. Technol. 2009, 43 (24), 9216-22; DOI 10.1021/es9015553.

534 5. Keller, A. A.; Lazareva, A., Predicted Releases of Engineered Nanomaterials: From Global to 535 Regional to Local. Environ. Sci. Technol. Lett. 2014, 1 (1), 65-70; DOI 10.1021/ez400106t.

536 6. Marschner, P.; Crowley, D.; Yang, C. H., Development of specific rhizosphere bacterial 537 communities in relation to plant species, nutrition and soil type. Plant Soil 2004, 261 (1-2), 199-208; 538 DOI 10.1023/B:PLSO.0000035569.80747.c5.

539 7. Ge, Y.; Schimel, J. P.; Holden, P. A., Evidence for negative effects of $\mathrm{TiO} 2$ and $\mathrm{ZnO}$ 540 nanoparticles on soil bacterial communities. Environ. Sci. Technol. 2011, 45 (4), 1659-64; DOI $541 \quad 10.1021 / \mathrm{es} 103040 \mathrm{t}$.

542 8. Simonin, M.; Guyonnet, J. P.; Martins, J. M.; Ginot, M.; Richaume, A., Influence of soil 543 properties on the toxicity of $\mathrm{TiO}(2)$ nanoparticles on carbon mineralization and bacterial abundance. $J$. 544 Hazard. Mater. 2015, 283, 529-35; DOI 10.1016/j.jhazmat.2014.10.004.

545 9. Frenk, S.; Ben-Moshe, T.; Dror, I.; Berkowitz, B.; Minz, D., Effect of metal oxide 546 nanoparticles on microbial community structure and function in two different soil types. PLoS ONE 547 2013, 8 (12), e84441; DOI 10.1371/journal.pone.0084441.

548 10. Colman, B. P.; Arnaout, C. L.; Anciaux, S.; Gunsch, C. K.; Hochella, M. F., Jr.; Kim, B.; 549 Lowry, G. V.; McGill, B. M.; Reinsch, B. C.; Richardson, C. J.; Unrine, J. M.; Wright, J. P.; Yin, L.; 550 Bernhardt, E. S., Low concentrations of silver nanoparticles in biosolids cause adverse ecosystem 551 responses under realistic field scenario. PLoS ONE 2013, 8 (2), e57189; DOI 552 10.1371/journal.pone.0057189.

553 11. Ge, Y.; Priester, J. H.; Van De Werfhorst, L. C.; Walker, S. L.; Nisbet, R. M.; An, Y. J.; 554 Schimel, J. P.; Gardea-Torresdey, J. L.; Holden, P. A., Soybean plants modify metal oxide 555 nanoparticle effects on soil bacterial communities. Environ. Sci. Technol. 2014, 48 (22), 13489-96; 556 DOI 10.1021/es5031646. 
557 12. Philippot, L.; Raaijmakers, J. M.; Lemanceau, P.; van der Putten, W. H., Going back to the 558 roots: the microbial ecology of the rhizosphere. Nat. Rev. Microbiol. 2013, 11 (11), 789-99; DOI $55910.1038 /$ nrmicro3109.

560 13. McNear Jr, D., The rhizosphere-roots, soil and everything in between. Nat. Educ. Knowl. $5612013,4(3): 1$.

562 14. Gottschalk, F.; Sun, T.; Nowack, B., Environmental concentrations of engineered 563 nanomaterials: review of modeling and analytical studies. Environ. Pollut. 2013, 181, 287-300; DOI $564 \quad 10.1016 /$ j.envpol.2013.06.003.

565 15. Park, B.; Donaldson, K.; Duffin, R.; Tran, L.; Kelly, F.; Mudway, I.; Morin, J. P.; Guest, R.; 566 Jenkinson, P.; Samaras, Z.; Giannouli, M.; Kouridis, H.; Martin, P., Hazard and risk assessment of a 567 nanoparticulate cerium oxide-based diesel fuel additive - a case study. Inhal. Toxicol. 2008, 20 (6), 568 547-66; DOI 10.1080/08958370801915309.

569 16. Gottschalk, F.; Lassen, C.; Kjoelholt, J.; Christensen, F.; Nowack, B., Modeling flows and 570 concentrations of nine engineered nanomaterials in the Danish environment. Int. J. Environ. Res. 571 Public Health 2015, 12 (5), 5581-602; DOI 10.3390/ijerph120505581.

572 17. Auffan, M.; Bottero, J.-Y.; Chanéac, C.; Rose, J., Inorganic manufactured nanoparticles: how 573 their physicovhemical properties influence their biological effect in aqueous environments. $574 \quad$ Nanomedicine 2010, 5 (6), 999-1007; DOI 10.2217/nnm.10.61.

575 18. Yu, T.; Malugin, A.; Ghandehari, H., Impact of silica nanoparticle design on cellular toxicity 576 and hemolytic activity. ACS Nano 2011, 5 (7), 5717-28; DOI 10.1021/nn2013904.

577 19. Xu, C.; Qu, X. G., Cerium oxide nanoparticle: a remarkably versatile rare earth nanomaterial 578 for biological applications. Npg Asia Materials 2014, 6 (3), e90; DOI 10.1038/am.2013.88.

579 20. Auffan, M.; Tella, M.; Santaella, C.; Brousset, L.; Pailles, C.; Barakat, M.; Espinasse, B.; 580 Artells, E.; Issartel, J.; Masion, A.; Rose, J.; Wiesner, M. R.; Achouak, W.; Thiery, A.; Bottero, J. Y., 581 An adaptable mesocosm platform for performing integrated assessments of nanomaterial risk in 582 complex environmental systems. Sci. Rep. 2014, 4, 5608; DOI 10.1038/srep05608.

583 21. Tella, M.; Auffan, M.; Brousset, L.; Issartel, J.; Kieffer, I.; Pailles, C.; Morel, E.; Santaella, C.; 584 Angeletti, B.; Artells, E.; Rose, J.; Thiery, A.; Bottero, J. Y., Transfer, Transformation, and Impacts of 
585 Ceria Nanomaterials in Aquatic Mesocosms Simulating a Pond Ecosystem. Environ. Sci. Technol. 586 2014, 48 (16), 9004-9013; DOI 10.1021/es501641b.

587 22. Tella, M.; Auffan, M.; Brousset, L.; Morel, E.; Proux, O.; Chaneac, C.; Angeletti, B.; Pailles, 588 C.; Artells, E.; Santaella, C.; Rose, J.; Thiery, A.; Bottero, J. Y., Chronic dosing of a simulated pond 589 ecosystem in indoor aquatic mesocosms: fate and transport of $\mathrm{CeO} 2$ nanoparticles. Environ. Sci. Nano 590 2015, 2 (6), 653-663; DOI 10.1039/c5en00092k.

591 23. Singh, R.; Singh, S., Role of phosphate on stability and catalase mimetic activity of cerium 592 oxide nanoparticles. Colloids Surf. B 2015, 132 (0), 78-84; DOI 10.1016/j.colsurfb.2015.05.005.

593 24. Dowd, S. E.; Callaway, T. R.; Wolcott, R. D.; Sun, Y.; McKeehan, T.; Hagevoort, R. G.; 594 Edrington, T. S., Evaluation of the bacterial diversity in the feces of cattle using 16S rDNA bacterial 595 tag-encoded FLX amplicon pyrosequencing (bTEFAP). BMC Microbiol. 2008, 8 (1), 125; DOI Artn $59612510.1186 / 1471-2180-8-125$.

597 25. Caporaso, J. G.; Kuczynski, J.; Stombaugh, J.; Bittinger, K.; Bushman, F. D.; Costello, E. K.; 598 Fierer, N.; Pena, A. G.; Goodrich, J. K.; Gordon, J. I.; Huttley, G. A.; Kelley, S. T.; Knights, D.; 599 Koenig, J. E.; Ley, R. E.; Lozupone, C. A.; McDonald, D.; Muegge, B. D.; Pirrung, M.; Reeder, J.; 600 Sevinsky, J. R.; Turnbaugh, P. J.; Walters, W. A.; Widmann, J.; Yatsunenko, T.; Zaneveld, J.; Knight, 601 R., QIIME allows analysis of high-throughput community sequencing data. Nat. Methods 2010, 7 (5), 602 335-6; DOI 10.1038/nmeth.f.303.

603 26. Zhang, J.; Guo, Z.; Xue, Z.; Sun, Z.; Zhang, M.; Wang, L.; Wang, G.; Wang, F.; Xu, J.; Cao, 604 H.; Xu, H.; Lv, Q.; Zhong, Z.; Chen, Y.; Qimuge, S.; Menghe, B.; Zheng, Y.; Zhao, L.; Chen, W.; 605 Zhang, H., A phylo-functional core of gut microbiota in healthy young Chinese cohorts across 606 lifestyles, geography and ethnicities. ISME J. 2015, 9 (9), 1979-90; DOI 10.1038/ismej.2015.11.

607 27. Benjamini, Y.; Hochberg, Y., Controlling the False Discovery Rate - a Practical and Powerful 608 Approach to Multiple Testing. J. R. Stat. Soc. Series B Methodol. 1995, 57 (1), 289-300; DOI $609 \quad 10.2307 / 2346101$.

610 28. Schlaeppi, K.; Dombrowski, N.; Oter, R. G.; Ver Loren van Themaat, E.; Schulze-Lefert, P., 611 Quantitative divergence of the bacterial root microbiota in Arabidopsis thaliana relatives. Proc. Natl. 612 Acad. Sci. U S A 2014, 111 (2), 585-92; DOI 10.1073/pnas.1321597111. 
613 29. Caldwell, B. A., Enzyme activities as a component of soil biodiversity: A review. 614 Pedobiologia 2005, 49 (6), 637-644; DOI 10.1016/j.pedobi.2005.06.003.

615 30. Lynch, M. D.; Neufeld, J. D., Ecology and exploration of the rare biosphere. Nat. Rev. 616 Microbiol. 2015, 13 (4), 217-29; DOI 10.1038/nrmicro3400.

617 31. Haichar, F. Z.; Marol, C.; Berge, O.; Rangel-Castro, J. I.; Prosser, J. I.; Balesdent, J.; Heulin, 618 T.; Achouak, W., Plant host habitat and root exudates shape soil bacterial community structure. ISME 619 J. 2008, 2 (12), 1221-30; DOI 10.1038/ismej.2008.80.

620 32. Josko, I.; Oleszczuk, P.; Futa, B., The effect of inorganic nanoparticles ( $\mathrm{ZnO}, \mathrm{Cr} 2 \mathrm{O} 3, \mathrm{CuO}$ 621 and $\mathrm{Ni}$ ) and their bulk counterparts on enzyme activities in different soils. Geoderma 2014, 232, 528622 537; DOI 10.1016/j.geoderma.2014.06.012.

623 33. Trasar-Cepeda, C.; Gil-Sotres, F.; Leiros, M. C., Thermodynamic parameters of enzymes in 624 grassland soils from Galicia, NW Spain. Soil Biol. Biochem. 2007, 39 (1), 311-319; DOI 625 10.1016/j.soilbio.2006.08.002.

626 34. Lozupone, C.; Knight, R., UniFrac: a new phylogenetic method for comparing microbial 627 communities. Appl. Environ. Microbiol. 2005, 71 (12), 8228-35; DOI 10.1128/AEM.71.12.8228$628 \quad 8235.2005$.

629 35. Wang, X. F.; Bao, H. D.; Cheng, J. M., The Effect of nanoFe3O4 Particles on the Soil Urease 630 and Catalase Activity. Adv. Mater. Res. 2014, 864-867, 853-856; DOI $631 \quad 10.4028 /$ www.scientific.net/AMR.864-867.853.

632 36. Yadav, R.; Patra, A.; Purakayastha, T.; Singh, R.; Kumar, C., Effect of Engineered 633 Nanoparticles of Fe and Zn Oxides on Enzyme Activity and Bacterial Abundance in Soil at Ambient 634 and Elevated Atmospheric CO2. Proc. Natl. Acad. Sci. India Sect. Biol. Sci. 2014, 84 (3), 649-656; 635 DOI 10.1007/s40011-014-0316-9.

636 37. Du, W.; Sun, Y.; Ji, R.; Zhu, J.; Wu, J.; Guo, H., TiO2 and ZnO nanoparticles negatively 637 affect wheat growth and soil enzyme activities in agricultural soil. J. Environ. Monit. 2011, 13 (4), 638 822-8; DOI 10.1039/c0em00611d. 
639 38. Nannipieri, P. The potential use of soil enzymes as indicators of productivity, sustainability

640 and pollution. In Soil biota: management in sustainable farming systems; Nannipieri, P., Pankhurst,

641 C., Doube, B., Gupta, V., Grace, P., Eds.; CSIRO Publishing: Adelaide 1994; pp 238-244.

642 39. Pelletier, D. A.; Suresh, A. K.; Holton, G. A.; McKeown, C. K.; Wang, W.; Gu, B.;

643 Mortensen, N. P.; Allison, D. P.; Joy, D. C.; Allison, M. R.; Brown, S. D.; Phelps, T. J.; Doktycz, M.

644 J., Effects of engineered cerium oxide nanoparticles on bacterial growth and viability. Appl. Environ.

645 Microbiol. 2010, 76 (24), 7981-9; DOI 10.1128/AEM.00650-10.

646 40. Hemala, L.; Zhang, D.; Margesin, R., Cold-active antibacterial and antifungal activities and 647 antibiotic resistance of bacteria isolated from an alpine hydrocarbon-contaminated industrial site. Res. 648 Microbiol. 2014, 165 (6), 447-56; DOI 10.1016/j.resmic.2014.05.035.

649 41. Máthé, I.; Benedek, T.; Táncsics, A.; Palatinszky, M.; Lányi, S.; Márialigeti, K., Diversity, 650 activity, antibiotic and heavy metal resistance of bacteria from petroleum hydrocarbon contaminated 651 soils located in Harghita County (Romania). Int. Biodeterior. Biodegrad. 2012, 73, 41-49; DOI $652 \quad 10.1016 /$ j.ibiod.2012.05.018.

653 42. Stancu, M. M.; Grifoll, M., Multidrug resistance in hydrocarbon-tolerant Gram-positive and 654 Gram-negative bacteria. J. Gen. Appl. Microbiol. 2011, 57 (1), 1-18; DOI 10.2323/jgam.57.1.

655 43. Jia, S.; Shi, P.; Hu, Q.; Li, B.; Zhang, T.; Zhang, X. X., Bacterial Community Shift Drives 656 Antibiotic Resistance Promotion during Drinking Water Chlorination. Environ. Sci. Technol. 2015, 49 657 (20), 12271-9; DOI 10.1021/acs.est.5b03521.

658 44. Kane, S. R.; Chakicherla, A. Y.; Chain, P. S.; Schmidt, R.; Shin, M. W.; Legler, T. C.; Scow, 659 K. M.; Larimer, F. W.; Lucas, S. M.; Richardson, P. M.; Hristova, K. R., Whole-genome analysis of 660 the methyl tert-butyl ether-degrading beta-proteobacterium Methylibium petroleiphilum PM1. $J$. 661 Bacteriol. 2007, 189 (5), 1931-45; DOI 10.1128/JB.01259-06.

662 45. Yergeau, E.; Sanschagrin, S.; Maynard, C.; St-Arnaud, M.; Greer, C. W., Microbial 663 expression profiles in the rhizosphere of willows depend on soil contamination. ISME J. 2014, 8 (2), 664 344-58; DOI 10.1038/ismej.2013.163.

665 46. Mendes, R.; Kruijt, M.; de Bruijn, I.; Dekkers, E.; van der Voort, M.; Schneider, J. H.; Piceno, 666 Y. M.; DeSantis, T. Z.; Andersen, G. L.; Bakker, P. A.; Raaijmakers, J. M., Deciphering the 
667 rhizosphere microbiome for disease-suppressive bacteria. Science 2011, 332 (6033), 1097-100; DOI $668 \quad 10.1126 /$ science.1203980.

669 47. Cretoiu, M. S.; Korthals, G. W.; Visser, J. H.; van Elsas, J. D., Chitin amendment increases 670 soil suppressiveness toward plant pathogens and modulates the actinobacterial and oxalobacteraceal 671 communities in an experimental agricultural field. Appl. Environ. Microbiol. 2013, 79 (17), 5291-301; 672 DOI 10.1128/AEM.01361-13.

673 48. Kinkel, L. L.; Schlatter, D. C.; Bakker, M. G.; Arenz, B. E., Streptomyces competition and co674 evolution in relation to plant disease suppression. Res. Microbiol. 2012, 163 (8), 490-9; DOI 675 10.1016/j.resmic.2012.07.005.

676 49. Li, X. G.; Zhang, Y. N.; Ding, C. F.; Jia, Z. J.; He, Z. L.; Zhang, T. L.; Wang, X. X., Declined 677 soil suppressiveness to Fusarium oxysporum by rhizosphere microflora of cotton in soil sickness. Biol. 678 Fertil. Soils 2015, 51 (8), 935-946; DOI 10.1007/s00374-015-1038-8.

679 50. Yang, J. I.; Ruegger, P. M.; McKenry, M. V.; Becker, J. O.; Borneman, J., Correlations 680 between root-associated microorganisms and peach replant disease symptoms in a California soil. 681 PLoS ONE 2012, 7 (10), e46420; DOI 10.1371/journal.pone.0046420.

682 51. Anderson, M.; Habiger, J., Characterization and identification of productivity-associated 683 rhizobacteria in wheat. Appl. Environ. Microbiol. 2012, 78 (12), 4434-46; DOI 10.1128/AEM.0746668411.

685 52. Gopalakrishnan, S.; Vadlamudi, S.; Bandikinda, P.; Sathya, A.; Vijayabharathi, R.; Rupela, 686 O.; Kudapa, H.; Katta, K.; Varshney, R. K., Evaluation of Streptomyces strains isolated from herbal 687 vermicompost for their plant growth-promotion traits in rice. Microbiol. Res. 2014, 169 (1), 40-8; DOI 688 10.1016/j.micres.2013.09.008.

689 53. Zhao, L.; Peralta-Videa, J. R.; Varela-Ramirez, A.; Castillo-Michel, H.; Li, C.; Zhang, J.; 690 Aguilera, R. J.; Keller, A. A.; Gardea-Torresdey, J. L., Effect of surface coating and organic matter on 691 the uptake of $\mathrm{CeO} 2 \mathrm{NPs}$ by corn plants grown in soil: Insight into the uptake mechanism. J. Hazard. 692 Mater. 2012, 225-226, 131-8; DOI 10.1016/j.jhazmat.2012.05.008. 
693 54. Denmead, O. T.; Shaw, R. H., Availability of Soil Water to Plants as Affected by Soil

694 Moisture Content and Meteorological Conditions. Agron. J. 1962, 54 (5), 385-\&; DOI 695 10.2134/agronj1962.00021962005400050005x.

696 55. Daly, K. R.; Mooney, S. J.; Bennett, M. J.; Crout, N. M.; Roose, T.; Tracy, S. R., Assessing 697 the influence of the rhizosphere on soil hydraulic properties using X-ray computed tomography and 698 numerical modelling. J. Exp. Bot. 2015, 66 (8), 2305-14; DOI 10.1093/jxb/eru509.

699 56. Solovitch, N.; Labille, J.; Rose, J.; Chaurand, P.; Borschneck, D.; Wiesner, M. R.; Bottero, J. 700 Y., Concurrent aggregation and deposition of $\mathrm{TiO} 2$ nanoparticles in a sandy porous media. Environ. 701 Sci. Technol. 2010, 44 (13), 4897-902; DOI 10.1021/es1000819.

702 57. Choi, E. J.; Jin, H. M.; Lee, S. H.; Math, R. K.; Madsen, E. L.; Jeon, C. O., Comparative 703 genomic analysis and benzene, toluene, ethylbenzene, and o-, m-, and p-xylene (BTEX) degradation 704 pathways of Pseudoxanthomonas spadix BD-a59. Appl. Environ. Microbiol. 2013, 79 (2), 663-71; 705 DOI 10.1128/AEM.02809-12.

706 58. Dowding, J. M.; Das, S.; Kumar, A.; Dosani, T.; McCormack, R.; Gupta, A.; Sayle, T. X.; 707 Sayle, D. C.; von Kalm, L.; Seal, S.; Self, W. T., Cellular interaction and toxicity depend on 708 physicochemical properties and surface modification of redox-active nanomaterials. ACS Nano 2013, 7097 (6), 4855-68; DOI 10.1021/nn305872d.

710 59. Estevez, A. Y.; Pritchard, S.; Harper, K.; Aston, J. W.; Lynch, A.; Lucky, J. J.; Ludington, J. 711 S.; Chatani, P.; Mosenthal, W. P.; Leiter, J. C.; Andreescu, S.; Erlichman, J. S., Neuroprotective 712 mechanisms of cerium oxide nanoparticles in a mouse hippocampal brain slice model of ischemia. 713 Free Radic. Biol. Med. 2011, 51 (6), 1155-63; DOI 10.1016/j.freeradbiomed.2011.06.006.

714 60. Heckman, K. L.; DeCoteau, W.; Estevez, A.; Reed, K. J.; Costanzo, W.; Sanford, D.; Leiter, J. 715 C.; Clauss, J.; Knapp, K.; Gomez, C.; Mullen, P.; Rathbun, E.; Prime, K.; Marini, J.; Patchefsky, J.; 716 Patchefsky, A. S.; Hailstone, R. K.; Erlichman, J. S., Custom cerium oxide nanoparticles protect 717 against a free radical mediated autoimmune degenerative disease in the brain. ACS Nano 2013, 7 (12), 718 10582-96; DOI 10.1021/nn403743b. 
719 61. Hirst, S. M.; Karakoti, A. S.; Tyler, R. D.; Sriranganathan, N.; Seal, S.; Reilly, C. M., Anti720 inflammatory Properties of Cerium Oxide Nanoparticles. Small 2009, 5 (24), 2848-2856; DOI $721 \quad 10.1002 / \mathrm{smll} .200901048$.

722 62. Thill, A.; Zeyons, O.; Spalla, O.; Chauvat, F.; Rose, J.; Auffan, M.; Flank, A. M., Cytotoxicity 723 of $\mathrm{CeO} 2$ nanoparticles for Escherichia coli. Physico-chemical insight of the cytotoxicity mechanism. 724 Environ. Sci. Technol. 2006, 40 (19), 6151-6; DOI 10.1021/es060999b.

725 63. Barton, L. E.; Auffan, M.; Bertrand, M.; Barakat, M.; Santaella, C.; Masion, A.; Borschneck, 726 D.; Olivi, L.; Roche, N.; Wiesner, M. R.; Bottero, J. Y., Transformation of pristine and citrate727 functionalized $\mathrm{CeO} 2$ nanoparticles in a laboratory-scale activated sludge reactor. Environ. Sci. 728 Technol. 2014, 48 (13), 7289-96; DOI 10.1021/es404946y.

729 64. Cornelis, G.; Ryan, B.; McLaughlin, M. J.; Kirby, J. K.; Beak, D.; Chittleborough, D., 730 Solubility and batch retention of $\mathrm{CeO} 2$ nanoparticles in soils. Environ. Sci. Technol. 2011, 45 (7), 731 2777-82; DOI 10.1021/es103769k.

732 65. Klitzke, S.; Metreveli, G.; Peters, A.; Schaumann, G. E.; Lang, F., The fate of silver 733 nanoparticles in soil solution--Sorption of solutes and aggregation. Sci. Total Environ. 2015, 535, 54734 60; DOI 10.1016/j.scitotenv.2014.10.108.

735 66. Ling, W.; Sun, R.; Gao, X.; Xu, R.; Li, H., Low-molecular-weight organic acids enhance 736 desorption of polycyclic aromatic hydrocarbons from soil. Eur. J. Soil Sci. 2015, 66 (2), 339-347; DOI $737 \quad 10.1111 /$ ejss.12227.

738 67. Whitley, A. R.; Levard, C.; Oostveen, E.; Bertsch, P. M.; Matocha, C. J.; von der Kammer, F.; 739 Unrine, J. M., Behavior of Ag nanoparticles in soil: effects of particle surface coating, aging and 740 sewage sludge amendment. Environ. Pollut. 2013, 182, 141-9; DOI 10.1016/j.envpol.2013.06.027. 
a)

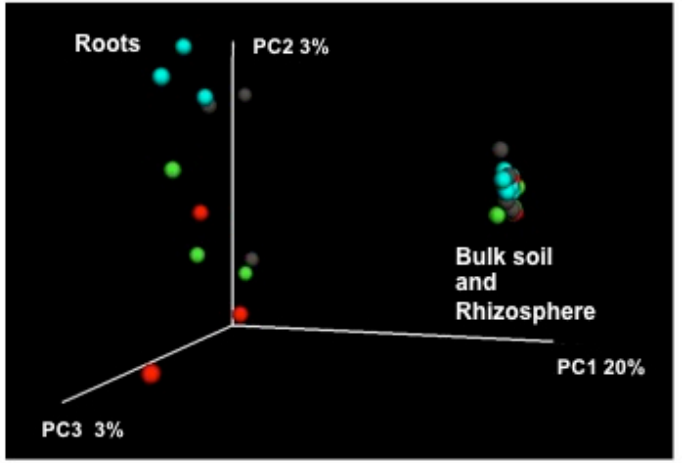

b)

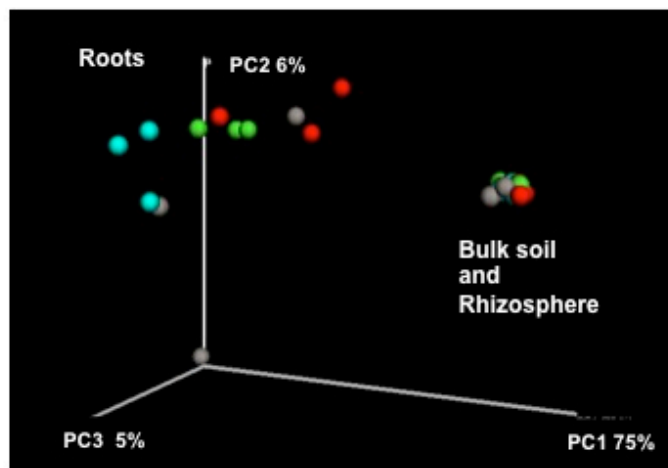

c)

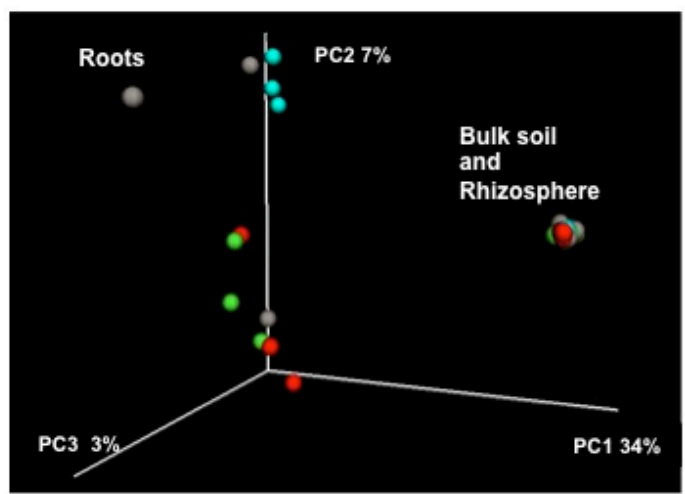

Figure 1: 3D beta diversity presented as PCoA plots depicting the clusters of bacterial communities within the different compartments (left: roots; right: rhizosphere and bulk soil) for the nanoceria treatments $\mathrm{CeO}_{2}-\mathrm{R}$ (green), $\mathrm{CeO}_{2}-\mathrm{U}$ (blue), coated $\mathrm{CeO}_{2}$ (grey) and controls (red). Unweighted UniFrac (a), weighted UniFrac (b), and Bray Curtis (c) distance metrics. The percent variation explained by the PCs is indicated on the axes and refers to the fraction of the total variance. Statistical analysis (PERMANOVA) of unweighted and weighted UniFrac as well as Bray-Curtis distance metrics revealed clustering of microbial communities based on the soil compartment factor (Fig. 1a, $\mathrm{P}=0.0001$; Fig. 1b $\mathrm{P}=0.0001$; Fig. $1 \mathrm{c}, \mathrm{P}=0.001)$ but not on nanoceria treatment $(\mathrm{P}>0.05)$. 


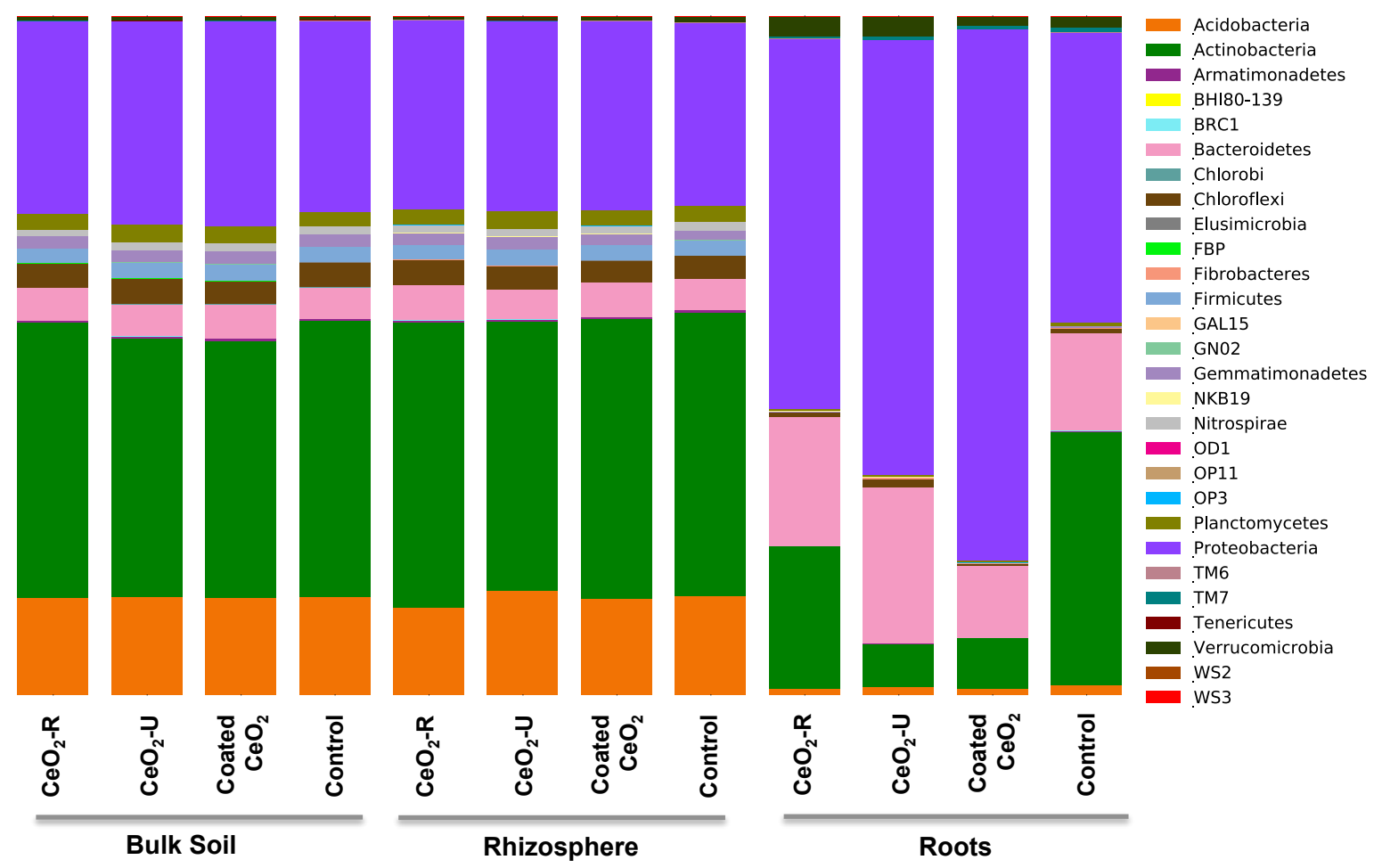

Figure 2: Relative abundance of major phyla in bulk soil, rhizosphere and root compartments for soil enhanced with nanoceria (pristine $\mathrm{CeO}_{2}-\mathrm{R}, \mathrm{CeO}_{2}-\mathrm{U}$ and citrate-coated $\mathrm{CeO}_{2}$ ) at $1 \mathrm{mg} \cdot \mathrm{kg}^{-1}$ and the respective controls. Significant differences were found in the root compartment and are summarized in Table S5. 
Table 1: Enzymatic activities in the rhizosphere of canola and in bulk soil after 30 days of exposure to nanoceria. Samples include pristine $\mathrm{CeO}_{2}-\mathrm{R}$ and $\mathrm{CeO}_{2}-\mathrm{U}$, and coated $\mathrm{CeO}_{2}\left(1 \mathrm{mg} \cdot \mathrm{kg}^{-1}\right)$ and controls. Values in bold denote statistically significant differences from controls (one-way ANOVA, post-hoc Student-Newman-Keuls test; $\mathrm{P}<0.05$ )

\begin{tabular}{|c|c|c|c|c|c|c|c|c|}
\hline \multirow[t]{2}{*}{ Enzymatic activity } & \multicolumn{4}{|c|}{ Rhizosphere } & \multicolumn{4}{|c|}{ Bulk Soil } \\
\hline & Control & $\mathrm{CeO}_{2}-\mathrm{R}$ & Coated-CeO & $\mathrm{CeO}_{2}-\mathrm{U}$ & Control & $\mathrm{CeO}_{2}-\mathrm{R}$ & Coated-CeO & $\mathrm{CeO}_{2}-\mathrm{U}$ \\
\hline $\begin{array}{l}\text { Catalase } \\
\mu \mathrm{mol} \mathrm{KMnO}_{4} \mathrm{~g}^{-1} \text { dry soil } \mathrm{min}^{-1}\end{array}$ & $5.4 \pm 0.4$ & $4.3 \pm 0.6$ & $4.2 \pm 0.2$ & $4.4 \pm 0.1$ & $3.9 \pm 0.3$ & $3.7 \pm 0.2$ & $3.5 \pm 0.3$ & $3.2 \pm 0.1$ \\
\hline $\begin{array}{l}\beta \text {-Glucosidase } \\
\mu \text { mol p-NP } \mathrm{g}^{-1} \text { dry soil } \mathrm{h}^{-1}\end{array}$ & $1.28 \pm 0.01$ & $1.037 \pm 0.07$ & $1.16 \pm 0.08$ & $1.05 \pm 0.11$ & $0.93 \pm 0.07$ & $0.86 \pm 0.03$ & $1.06 \pm 0.01$ & $0.90 \pm 0.05$ \\
\hline $\begin{array}{l}\text { Peroxidase } \\
\mu \mathrm{mol} \mathrm{h} \mathrm{h}^{-1} \mathrm{~g}^{-1}\end{array}$ & $0.170 \pm 0.002$ & $0.154 \pm 0.014$ & $0.152 \pm 0.006$ & $0.168 \pm 0.015$ & $0.158 \pm 0.030$ & $0.129 \pm 0.023$ & $0.157 \pm 0.033$ & $0.145 \pm 0.003$ \\
\hline $\begin{array}{l}\text { Phenoloxidase } \\
\mu \mathrm{mol} \mathrm{h}^{-1} \mathrm{~g}^{-1}\end{array}$ & $0.221 \pm 0.008$ & $0.213 \pm 0.03$ & $0.210 \pm 0.004$ & $0.214 \pm 0.014$ & $0.238 \pm 0.029$ & $0.189 \pm 0.058$ & $0.194 \pm 0.038$ & $0.173 \pm 0.004$ \\
\hline $\begin{array}{l}\text { Acid Phosphatase } \\
\mu \mathrm{mol} p-\mathrm{NP} \mathrm{g}^{-1} \text { dry soil. } \mathrm{h}^{-1}\end{array}$ & $0.78 \pm 0.03$ & $0.71 \pm 0.06$ & $0.72 \pm 0.08$ & $0.69 \pm 0.11$ & $0.63 \pm 0.04$ & $0.60 \pm 0.08$ & $0.72 \pm 0.15$ & $0.59 \pm 0.01$ \\
\hline $\begin{array}{l}\text { Alkaline Phosphatase } \\
\mu \text { mol p-NP } g^{-1} \text { dry soil. } h^{-1}\end{array}$ & $0.90 \pm 0.04$ & $0.73 \pm 0.10$ & $0.79 \pm 0.05$ & $0.73 \pm 0.04$ & $0.63 \pm 0.03$ & $0.61 \pm 0.02$ & $0.65 \pm 0.03$ & $0.61 \pm 0.07$ \\
\hline $\begin{array}{l}\text { Protease } \\
\mu \mathrm{g} \text { l-tyrosine released } . \mathrm{g}^{-1} \text { dry soil } \mathrm{h}^{-1}\end{array}$ & $133 \pm 33$ & $105 \pm 16$ & $119 \pm 18$ & $123 \pm 17$ & $93 \pm 20$ & $110 \pm 16$ & $104 \pm 18$ & $90 \pm 28$ \\
\hline
\end{tabular}

p-NP: para-nitrophenyl 
TOC Abstract :

$$
\begin{gathered}
\text { Impact of nanoCeO } \\
\text { on microbial activity } \\
\text { and community structure }
\end{gathered}
$$

Bulk soil

Rhizosphere

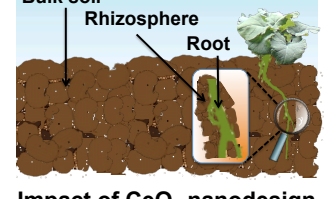

Impact of $\mathrm{CeO}_{2}$ nanodesign size and coating

$\mathrm{CeO}_{2}$ 